\title{
Annita de Castilho Marcondes Cabral
}

\section{Contribuição para a Psicologia do Brasil}

A questão da busca da identidade do psicólogo brasileiro, que na realidade traz em seu bojo outras tantas, que como ela são fundamentais; a questão da autonomia universitária com intra e extra fluxos de pesquisa cientifica; a questäo do diálogo entre a ciência e a realidade brasileira e mundial - soam aos nossos ouvidos como sendo extremamente atuais.

Porém, se nos detivermos um pouco mais sobre esses assuntos, poderemos constatar que tais questoes já se delineiam num tempo que nos antecede.

A professora Annita de Castilho Marcondes Cabral não pode ser esquecida, quando o tcma perpassa as questóes acima referidas.

Em 1947, recém chegada dos EUA, onde-esteve à guisa de aperfeiçoar os seus estudos, conquistando o titulo de mestre em psicologia, discipula de Bethelheim, ex-aluna di Lourenço Filho; na USP; ocupa a cátedra de psicologia, sendo a terceira catedrática num: sucessão onde estiveram, em primeiro lugar, Jean Maüguê, e em seguida, Otto Klineberg, d. quem Annita fora assistente. Pessoa dotada de extrema inteligência, ministrava a maior parte das disciplinas da cadeira, tendo introduzido a Gestalt no curso, área na qual se especializou.

Consciente da necessidade de desvincular a cadeira de Psicologia da seção de Filosofia (na época, a Psicologia era um pequeno núcleo inserido na seção de Filosofia, que por sua vez, fazia parte da faculdade de Filosofia Ciências e Letras da USP). Annita empreende uma luta neste sentido, pois percebia que o caminho para a conquista da autonomia da psicologia, enquanto curso propriamente dito, iniciava-se ai, nesta separação da seção de filosofia.

Em 1958, juntamente com Cícero Cristiano de Souza, Anibal Silveira e Durval Marcondes, Annita consegue criar o Curso de Especializaçāo em Psicologia Clínica da Cadeira de Psicologia da FFCL da USP, curso pelo qual continua lutando, promovendo o aporte de idéias da Europa e dos EUA, através de sucessivos intercâmbios com professores eminentes, trazidos invariavelmente, por intermédio da professora Annita; elaborando curriculos mais amplos e adequados, visando a conquista de um verdadeiro espaço para a psicologia enquanto ciência e curso de formaçāo.

No periodo compreendido entre 1947 e 1958. Annita faz circular as suas idéias através de importantes publicaçoes - A Psicologia no Brasil (1950) - no boletim da FFCL - uma das grandes obras, que expóe e analisa até a data, o percurso da Psicologia no Brasil.

Em 1953, é publicada no Brasil a obra - Psicologia Moderna Coordenada por Otto Klineberg, tendo Annita Cabral como uma das colaboradoras.- Esta obra oferece o panorama do nivel que a Psicologia atingiu no país, demonstrando ainda, a transição da influência das idéias européias para as norte-americanas.

A professora Annita constitui um importante marco para a Psicologia brasileira; $\mathrm{em}$ particular para a USP, pois a conquista do curso de especialização em Psicologia clínica abriu as portas para o estabelecimento do Depto e posterior Instituto de Psicologia, da própria clínica, onde os alunos poderiam exercer o lado prático do curso, além de se constituirem em agentes da função, não menos prioritária da Instituiçào Clinica, qué á funçào social.

A sua luta refletia inquietaçoes históricas do cidadão brasileiro, a luta por autonomia, por uma identidade propriamente dita, enquanto portadora do direito do saber e de um saber que produz os seus frutos, que certamente seräo degustados e reciclados por geraçoes futuras. 